\title{
Infinitiivien variaatio ja muutos Helsingissä
}

\author{
Olli Kuparinen
}

\section{Johdanto}

Lähettiin pämppää / pistettiin lääväks pari kämppää lauloi helsinkiläinen Teflon Brothers -yhtye vuoden 2015 kesähitissään. Lyhyessä otteessa on useita variaationtutkijoita kiinnostavia piirteitä, mutta tässä kirjoituksessa huomioni kohteena on infinitiivi, joka näyttää menettäneen sekä tunnuksensa että sijansa. Aineistona artikkelissa on käytetty Helsingin puhekielen pitkittäiskorpusta (Helpuhe 2014), joka koostuu 1970-, 1990- ja 2010-luvuilla tehdyistä haastatteluista. Infinitiiveistä tarkastelen kahta yleisintä: Ainfinitiivin historiallista latiivia ja MA-infinitiivin illatiivia. Jonkin verran kiinnitän huomiota myös käydä- ja olla-verbien inessiivitäydennyksiin. ${ }^{1}$

Infinitiivit ovat kiinnostaneet suomen kielen tutkijoita niin dialektologian kuin sosiolingvistiikan perinteessä. Erityisesti MA-infinitiivin illatiivimuodot ovat kuuluneet sekä aluemurteiden että kaupunkikielten tutkimuskohteisiin. Tunnuksellisten ja tunnuksettomien muotojen vaihtelua on tarkasteltu etenkin hämäläismurteiden alueella (Saukkonen 1965: 50-55; Itkonen 1989; Mustanoja 2011). Myös Helsingin puhekielen tutkimuksessa on kiinnitetty jonkin verran huomiota infinitiiveihin (Sorsakivi 1982; Paunonen 1995 [1982]; Lappalainen 2004). Viime vuosikymmeninä on julkaistu infinitiivejä käsittelevää tutkimusta toisaalta kieliopin (Herlin \& Visapää toim. 2005; Visapää 2008), toisaalta vanhan kirjakielen (Leino 2003) näkökulmasta. Kattavaa kuvausta infinitiivien variaatiosta puhekielessä ei kuitenkaan ole esitetty sitten Saukkosen (1965), minkä vuoksi tutkimukselleni on selvä tilaus.

Helsingin puhekielessä on viime vuosina yleistynyt lyhyt infinitiivimuoto, joka voi toimia sekä A-infinitiivin että MA-infinitiivin tehtävissä: pitää kertoo (Ainfinitiivi) - mennä kertoo (MA-infinitiivi). Tässä artikkelissa tarkastelen tällaisten yhteenlankeamisten syitä, seurauksia ja infinitiivien keskinäistä variaatiota Helsingin puhekielessä neljän vuosikymmenen ajanjaksolla. Tapahtuneita muutoksia analysoin

1. Artikkeli perustuu pro gradu -tutkielmaani (Kuparinen 2015) ja on kirjoitettu Koneen Säätiön apurahalla. Kiitän Unni-Päivä Leinoa, Liisa Mustanojaa, Jaakko Peltosta ja Jenni Santaharjua käsikirjoituksen kommentoinnista. Työn varhaisessa vaiheessa olen saanut apua myös Markus Hamuselta, mistä esitän kiitokset. Lisäksi kiitän Virittäjän kahta nimetöntä arvioijaa, joiden huomiot ovat parantaneet huomattavasti kirjoituksen laatua. 
muutosmallien (alaluku 2.2) avulla, mikä on suomalaisessa variaationtutkimuksessa ollut melko vähäistä (Kurki 2013: 211).

\section{Ilmiön tausta ja aineisto}

Tässä luvussa esittelen tutkimuskohteet ja tutkimuksen hypoteesit ja kysymykset. Jotta esittämäni tulokset asettuisivat paremmin kontekstiinsa ja olisivat lukijan helposti seurattavissa, esittelen infinitiivisysteemin taustaa laajasti alaluvussa 2.1. Vastaavasti tulosten seuraamisen helpottamiseksi kuvaan alaluvussa 2.2 lyhyesti teoriaa muutosmalleista. Alaluvussa 2.3 esittelen tutkimuksessa käytetyn aineiston ja sitä koskevat valinnat.

\subsection{Tutkimuskohteet ja -kysymykset}

Artikkeli keskittyy suomen kahden yleisimmän infinitiivimuodon tarkasteluun. Ainfinitiivin lyhyitä muotoja (latiiveja) on Lauseopin arkiston murreaineistossa 6,72 esiintymää 1 ooo tekstisanaa kohden ja MA-infinitiivin illatiiveja vastaavasti 5,73 (Herlin, Leino \& Visapää 2005: 17). Nämä kaksi infinitiivimuotoa ovat tehtäviltään samantapaisia, sillä molemmat ovat olleet historiallisesti tulosijaisia. Myöhemmin A-infinitiivin latiivisuus on hälvennyt ja se on liittynyt ennen kaikkea abstraktien verbien täydennykseksi (esim. voida). MA-infinitiivin illatiivi toimii puolestaan tyypillisesti sijansa mukaisesti konkreettisempien, paikallissijaista täydennystä vaativien verbien kanssa (esim. mennä). Kahden infinitiivin ${ }^{2}$ järjestelmä on yleinen itämerensuomalaisissa kielissä, ja näistä $t$ aineksen sisältänyt infinitiivi (suomessa siis A- ja E-infinitiivi) on vanhempi kuin MAinfinitiivi (Saukkonen 1965: 50). Joidenkin verbien infinitiivitäydennyksen laatu vaihtelee murretaustan mukaan (esim. alkaa, pystyä, joutua, ehtiä). Tunnetuin näistä verbeistä lienee alkaa, joka länsimurteissa on saanut täydennyksekseen tyypillisesti MA-infinitiivin illatiivin (alkaa tekemään) ja itämurteissa puolestaan A-infinitiivin latiivin (alkaa tehdä). Variaatiolle on nähty myös semanttisia syitä (Herlin 2012). (Infinitiivimuotojen historiasta ks. Saukkonen 1965: 237-247; 1966: 112.)

Vaikka kahdella tulosijainfinitiivillä onkin päällisin puolin melko selkeä työnjako, on systeemi silti osittain päällekkäinen. Esimerkiksi pohjoissaamessa käytetään tyypillisesti yhtä perusinfinitiiviä monissa eri tehtävissä eikä MA-infinitiiviä vastaavaa verbimuotoa ole käytössä lainkaan (Jomppanen 2009: 23; Saukkonen 1965: 50). Vastaavasti monissa indoeurooppalaisissa kielissä on vain yksi tulosijainen infinitiivi. Jaakko Leino onkin esittänyt (2003: 237), että suomessa saattaisi olla meneillään tendenssi kohti yhtä yleisinfinitiiviä indoeurooppalaisten kielten tapaan. Tutkimukseni tukee tätä havaintoa ainakin infinitiivien muodon kannalta: muutamat yleiset äänteenmuutokset johtavat suomen kahta yleisinfinitiiviä yhteen, mitä esittelen tau-

2. Suomen kielioppiperinteen viidestä infinitiivistä on nyttemmin yleisesti luovuttu ja infinitiivit luokitellaan yleensä kolmia: A-, E- ja MA-infinitiiviin (VISK \$ 120). Näistä kuitenkin A- ja E-infinitiivillä on vanhastaan yhteinen $t$-aines (Saukkonen 1965), joten voidaan puhua kahdesta infinitiivistä. Siro (1964) on puolestaan esittänyt, että syntaktisesti suomessa on vain yksi infinitiivi. Selvää kuitenkin on, että morfologisesti infinitiiviä merkitään itämerensuomalaisissa kielissä vähintään kahdella eri tavalla. 
lukossa 1. Kieliopissa mahdollisesti tapahtuvia muutoksia ja yhden infinitiivin teoriaa pohdin myöhemmin luvussa 4.

Taulukko 1.

Suomen verbityypit eri infinitiivimuodoissa.

\begin{tabular}{|c|c|c|c|c|}
\hline $\begin{array}{l}\text { Verbi- } \\
\text { tyyppi }\end{array}$ & $\begin{array}{l}\text { A-infinitiivin } \\
\text { latiivi }\end{array}$ & $\begin{array}{l}\text { MA-infinitiivin } \\
\text { illatiivi }\end{array}$ & $\begin{array}{l}\text { MA-tunnukseton } \\
\text { illatiivi }\end{array}$ & Lyhyt infinitiivi \\
\hline $\begin{array}{l}\text { 1. } A A, O A \text {, } \\
e A, \cup A, i A\end{array}$ & $\begin{array}{l}\text { antaa } \\
\text { kertoa }\end{array}$ & $\begin{array}{l}\text { antamaan } \\
\text { kertomaan }\end{array}$ & $\begin{array}{l}\text { antaan } \\
\text { kertoon }\end{array}$ & $\begin{array}{l}\text { antaa } \\
\text { kertoo }\end{array}$ \\
\hline 2. $d A$ & $\begin{array}{l}\text { saada } \\
\text { imuroida }\end{array}$ & $\begin{array}{l}\text { saamaan } \\
\text { imuroimaan }\end{array}$ & $\begin{array}{l}\text { *saan } \\
{ }^{*} \text { imuroiin }\end{array}$ & $\begin{array}{l}{ }^{*} \text { saa } \\
{ }^{*} \text { imuroi }\end{array}$ \\
\hline $\begin{array}{l}\text { 3. tA, } l A, \\
\text { rA, nA }\end{array}$ & $\begin{array}{l}\text { nousta } \\
\text { tulla }\end{array}$ & $\begin{array}{l}\text { nousemaan } \\
\text { tulemaan }\end{array}$ & $\begin{array}{l}\text { nouseen } \\
\text { tuleen }\end{array}$ & $\begin{array}{l}\text { ?nousee } \\
\text { ?tulee }\end{array}$ \\
\hline 4. $(t) A$ & pelata & pelaamaan & pelaan & pelaa \\
\hline 5. tarvita & tarvita & tarvitsemaan & $\begin{array}{l}\text { tarvitseen } \\
\text { tarviin/tartteen }\end{array}$ & $\begin{array}{l}\text { ?tarvitsee } \\
\text { ?tarvii/tarttee }\end{array}$ \\
\hline 6. vanheta & vanheta & vanhenemaan & $\begin{array}{l}\text { vanheneen } \\
\text { ?vanheen }\end{array}$ & $\begin{array}{l}\text { ?vanhenee } \\
\text { ?vanhee }\end{array}$ \\
\hline
\end{tabular}

Taulukossa 1 olen esittänyt suomen verbien muotoryhmät ja niiden variantit Ainfinitiivissä, MA-infinitiivin illatiivissa, MA-tunnuksettomassa illatiivissa ja lyhyessä infinitiivissä. Infinitiivien päätyminen lyhyiksi infinitiiveiksi voidaan näin johtaa muutaman äänteenmuutoksen kautta:
a) A-loppuisten vokaaliyhtymien assimiloituminen (kertoa $>$ kertoo)
b) MA-infinitiivin illatiivien MA-tunnuksettomuus (antamaan > antaan)
c) sananloppuisen $n$-äänteen kato (antaan $>$ antaa)
d) supistumaverbien analogiset muodot (pelata $>$ pelaa)

Näistä ensimmäinen (a) on Mantilan (2004: 326-327) havaintojen mukaan yleistymässä koko maassa, ja samansuuntaisia arvioita on partitiivimuotojen (esim. palloa > palloo) osalta esittänyt myös Paunonen (1995 [1982]: 110-113). Vokaaliyhtymien välillä on kuitenkin eroa: herkimmin pitkävokaalisina esiintyvät $e A$ ja $O A$, kun taas $U A$ ja $i A$ ovat perinteisesti säilyneet (ks. esim. mts. 106-127). Kohta b puolestaan voidaan yhdistää hämäläismurteiden vaikutukseen, joka Helsingissä onkin ollut suuri (mts. 13-15). Nuolijärvi ja Sorjonen (2005: 97) esittävät tämän piirteen olevan myös "hyvin ekspansiivinen tyyppi Etelä-Suomen kaupunkien ja erityisesti nuorten kielessä". Viimeinen (d) on vanhastaan etelähämäläisissä murteissa tavattu analoginen muoto, joka Itkosen (1964: 187-193) mukaan on seurausta ruotsinkielisten ja suomenkielisten puhujien yhteiselosta (ks. myös Itkonen 1989: 364-365). Muoto on säilynyt Helsingissä etenkin slangissa (Paunonen 2006: 37). 
Sananloppuisen $n$-äänteen kato (c) ei ole yhtä yksiselitteinen kuin muut esitellyt äänteenmuutokset. Absoluuttisessa lopussa kato on hyvin tyypillinen (Rapola 1966: 325) ja niin ikään sellaisissa tapauksissa, joissa se on osa taivutustunnusta. ${ }^{3}$ Nasaalin ja klusiilin edellä $n$ kuitenkin usein assimiloituu, ja assimilaatio voi tapahtua myös likvidan, j:n tai $v$ :n edellä (VISK $\$ 39$ ). Vokaalien edellä $n$ on Rapolan (mts. 327) mukaan yleisesti säilynyt. Tulosijainfinitiivejä helsinkiläislasten puheesta tutkinut Sorsakivi (1982: 383-384) kuitenkin esittää, että illatiivimuodoissa sananloppuinen $n$ ei katoa, vaan se liittyy sananloppuisen $k: n$ sandhikaavaan. Äänteen käyttäytymiseen sananrajalla ja mahdollisiin ongelmiin palaan vielä alaluvuissa 3.1 ja 3.2.

Taulukosta 1 huomataan myös, että kaikissa verbityypeissä edellä mainitut äänteenmuutokset eivät ole mahdollisia (tyyppi 2) tai verbin vartalosta johtuen A-infinitiivi ja MA-infinitiivin illatiivi päätyvät äänteenmuutosten jälkeen eri asuihin (tyypit 3,5 ja 6). ${ }^{4} d A$-verbit eivät voi menettää infinitiivin tunnusta sen paremmin A-infinitiivissä kuin MA-infinitiivissäkään, minkä takia olen merkinnyt näitä muotoja asteriskilla. Konsonanttivartaloisten ryhmä (tyyppi 3) sen sijaan päätyy MA-infinitiivin illatiivia vaativissa tapauksissa herkästi lyhyeen asuun (meen juoksee) mutta toimii lyhyenä infinitiivinä harvoin A-infinitiivitäydennystä vaativissa tehtävissä (voi juoksee). Sentyyppiset tapaukset kuin pitää saa ja pitää juoksee eivät siis vaikuta kovin todennäköisiltä. Tällaisia lipsahduksiksi tulkitsemiani esiintymiä on käyttämässäni aineistossa (Helpuhe 2014) vain muutamia. Tämä aiheuttaa haasteita aiemmin esittelemälleni ajatukselle yhden yleisinfinitiivin systeemistä, sillä $d A$-verbien ja konsonanttivartaloisten verbien osuus on tämän tutkimuksen kaikista infinitiiviesiintymistä noin $30 \%$. Palaan tähän alaluvussa 4.2.

Olen edellä esitellyt yleisinfinitiivien historiallista taustaa ja äänteenmuutoksista johtuvaa yhteenlankeamista. Tähän taustaan peilaten tutkin sitä, millaista yleisinfinitiivien sisäinen variaatio on ja miten se on muuttunut vuosikymmenten välillä. Toisekseen lyhyen infinitiivin muoto ja merkitys kaipaavat vielä selvittämistä: kytkeytyykö lyhyt infinitiivi A-infinitiiviin, MA-infinitiiviin vai yksikön kolmannen persoonan muotoon? Näitä seikkoja tarkastelen luvussa 3. Viimeisenä kysymyksenä (alaluku 4.2) pohdin koko infinitiivijärjestelmää: onko edellä esitetyissä äänteenmuutoksissa koko järjestelmän muutoksen siemen? Seuraavaksi esittelen kuitenkin mallit, joilla muutosta on kuvattu variaationtutkimuksessa.

\subsection{Muutosmallit}

Sosiolingvistiikan keskeisiä tutkimuskohteita on meneillään oleva kielenmuutos. Sitä on pyritty tarkastelemaan näennäisaikametodilla ja pitkittäisaineistojen valmistumisen myötä myös reaaliajassa (ks. esim. Kurki 2005: 31-37; Laasanen 2016). Keskeinen ero menetelmien välillä on se, että jälkimmäisen avulla voidaan tarkastella muutosta

3. Lehtonen (2006: 269-270) on kuitenkin havainnut, että 2000-luvun helsinkiläisnuorilla loppu-n katoaa usein myös verbin persoonapäätteestä (esim. mä sano).

4. Tyyppien 5 ja 6 esiintymiä on aineistossani niin vähän, että jätän ne tässä kokonaan tarkastelun ulkopuolelle. 
diakronisesti, kun taas näennäisaikamenetelmä tarkkailee yhtä hetkeä synkronisesti ja tekee sen perusteella ennusteita muutoksen suunnasta. Tämä perustuu pitkälti ajatukseen idiolektien muuttumattomuudesta ja niin sanottuun kriittisen iän hypoteesiin. Hypoteesin mukaan kielen oppiminen on helpointa tietyssä ikävaiheessa (lapsena tai viimeistään varhaisnuorena); tämän kriittisen iän jälkeen idiolektin ei enää katsota olennaisesti muuttuvan. (Laasanen 2016: 64-67; Meyerhoff 2011: 141.)

Toinen muutoksen tutkimuksen keskeisistä eronteoista liittyy puhujayhteisön ja yksilöiden väliseen suhteeseen. Idiolektien muutos voi poiketa yhteisön muutoksen suunnasta, tai nämä muutokset voivat olla samansuuntaisia. Näitä erilaisia vaihtoehtoja on esitellyt Labov (1994: 83) nelikentässä, jonka on suomeksi esittänyt Paunonen (2005; ks. myös Kurki 2013). Reaaliaikaisen aineiston avulla saadun informaation perusteella nelikenttää on vielä täydennetty elinikäisellä muutoksella (Sankoff 2005). Erilaiset muutosmallit on koottu taulukkoon 2.

Taulukko 2.

Muutosmallit (Labov 1994; Paunonen 2005; Sankoff 2005; Kurki 2013).

\begin{tabular}{l|l|l} 
& Yksilö & Yhteisö \\
\hline 1. Vakaus & vakaa & vakaa \\
\hline 2. Ikäsidonnainen muutos & muuttuva & vakaa \\
\hline 3. Sukupolvittainen muutos & vakaa & (asteittain) muuttuva \\
\hline 4. Yhteisöllinen muutos & muuttuva & muuttuva \\
\hline 5. Elinikäinen muutos & muuttuva & (asteittain) muuttuva \\
\hline
\end{tabular}

Tämän tutkimuksen tulosten osalta (luku 3) yksilön ja yhteisön suhde vaihtelee: tilanne ei ole vakaa, eikä muutos tapahdu myöskään yhteisöllisesti. Niinpä tutkimuksen kannalta keskeisiä muutosmalleja ovat ikäsidonnainen muutos, sukupolvittainen muutos ja elinikäinen muutos. Ikäsidonnaisessa muutoksessa on kyse siitä, että tietyssä elämänvaiheessa tai iässä yksilön kieli muuttuu hetkellisesti. Kun tämä vaihe on ohitettu, vaiheelle ominaiset piirteet heikkenevät tai väistyvät (Kurki 2013: 209). Näin koko yhteisön kielitilanne pysyy vakaana. Sukupolvittaisella muutoksella tarkoitetaan puolestaan tilannetta, jossa eri sukupolvien kielenkäyttö eroaa toisistaan eikä yksilöiden kieli muutu. Näin ajan kuluessa koko yhteisön kieli muuttuu. Ikäsidonnainen muutos ja sukupolvittainen muutos näyttävät yhdestä hetkestä tarkasteltuna samalta: yksittäinen sukupolvi eroaa muista sukupolvista. Elinikäinen muutos perustuu sukupolvittaiseen muutokseen, mutta sen sijaan, että idiolektit säilyisivät ennallaan, ne muuttuvat yhteisössä tapahtuvan sukupolvittaisen muutoksen suuntaan (Sankoff 2005; Kurki 2013). Wagner ja Sankoff (2011: 303-306) ovat kuitenkin muistuttaneet myös niin sanotusta vetäytyvästä elinikäisestä muutoksesta (engl. retrograde lifespan change) ${ }^{5}$, jossa idiolektien muutos onkin yhteisössä tapahtuvaan muutokseen nähden päinvastainen. Käsittelen muutosmalleja ja niiden sopimista infinitiivien muutoksen tarkasteluun tulosten yhteydessä (luku 3).

5. Suomennos Laasaselta (2016: 66). 


\subsection{Aineisto ja menetelmät}

Tutkimuksen aineistona käytän Helsingin puhekielen pitkittäiskorpusta (Helpuhe 2014). Aineisto on kerätty kolmella vuosikymmenellä (1972-1974, 1991-1992, 2013) ja sijoitettu myöhemmin osaksi CSC:n Kielipankkia. ${ }^{6}$ Informantit on ensimmäisellä kierroksella valittu kahdesta kaupunginosasta (Töölö ja Sörnäinen), kolmesta sosiaaliluokasta ja kolmesta ikäluokasta ja jaettu jotakuinkin tasan miehiin ja naisiin. Kaupunginosa- ja sosiaaliluokitus on myöhemmillä kierroksilla yhdistetty osoittamaan lähinnä informanttien koulutustaustaa.

Tässä tutkimuksessa olen tarkastellut taustamuuttujista vain ikää, koska sen on aiemmissa tutkimuksissa katsottu korreloivan taustamuuttujista voimakkaimmin kielen kanssa (esim. Lappalainen 2001; Buchstaller 2015). Kritiikkinä voidaan esittää, että aineistoon luodut ikäryhmät ovat väistämättä heterogeenisiä joukkoja, joita tutkittaessa yksittäisten puhujien idiolektit jäävät varjoon (Lappalainen 2004: 15; vrt. Kurki 2007: 150-151). Tutkimuksessa pyrin kuitenkin selvittämään ennen kaikkea koko infinitiivijärjestelmän tilannetta Helsingissä. Näin ollen ryhmien koostumukset eivät ole tässä tutkimuksessa ensisijaisia, vaan tarkoituksena on tutkia yksittäisiä piirteitä ja pyrkiä havaitsemaan niissä tapahtuvia muutoksia.

Olen poiminut ja luokitellut käsin aineistosta havaitsemani infinitiiviesiintymät. Ikäryhmien ja vuosikymmenten eroja olen tarkastellut tilastollisesti khiin neliö -testin (Pearson 1900) avulla. Testin nollahypoteesissa oletetaan, että vertailtavat ryhmät eivät eroa toisistaan. Otoksesta laskettu p-arvo on todennäköisyys sille, että havaittu arvo toteutuisi ilman eroa perusjoukossa eli selittyisi pelkästään otantavirheellä. Mitä pienempi p-arvo siis on, sitä enemmän tukea saadaan nollahypoteesin hylkäämiselle. Yleisesti rajana pidetään p-arvoa 0,05. Tutkimuksen tuloksissa esitän p-arvon lisäksi myös vapausasteiden lukumäärän (sulkeissa) ja testimuuttujan arvon (yhdysmerkin jälkeen) seuraavasti: $\mathrm{X}^{2}(2)=251,79, \mathrm{p}<0,001$. Khiin neliö -testiä hyödyntämällä aineistossa kenties muutenkin havaittavat muutokset saavat tilastollista tukea. Tätä kautta tutkimus kiinnittyy suomalaisen sosiolingvistiikan kvantitatiivisia metodeja painottaviin tutkimuksiin (esim. Kurki 2005; Mustanoja 2011; Priiki 2017).

Eri vuosikymmenillä kerätyt aineistot eivät määrällisesti täysin vastaa toisiaan, sillä 1970-luvun osalta tutkimus on kohdistunut 96 informantista koostuvaan ydinaineistoon, 1990-luvulla haastatteluja tehtiin 45 ja 2010-luvulta käytettävissäni oli 44 informantin haastattelu. Tästä aineistosta on litteroituna julkaistu vasta osa. 1990-luvun ja 2010-luvun aineistosta litteraatteja ei tätä tutkimusta tehdessäni ollut saatavilla vastaavassa määrin kuin 1970-luvun aineistosta. Näin ollen päädyin käyttämään vain osaa 1970-luvun aineistosta ja täydentämään 1990- ja 2010-luvun informanttien määrää kuuntelemalla haastatteluja ja poimimalla niistä infinitiiviesiintymät. 1990-luvun aineistosta olen kuunnellut 14 haastattelua ja 2010-luvun aineistosta 11. Tutkimukseen eri vuosikymmeniltä

6. Hankkeen käynnistäjänä toimi Terho Itkonen, mutta pääasiallisen vastuun 1970- ja 1990-lukujen aineistonkeruusta kantoi Heikki Paunonen, jonka ideasta syntyi myös viimeisin kierros. Vuodesta 2013 projektia on johtanut Hanna Lappalainen. Haastattelijoina ovat toimineet kaikilla vuosikymmenillä Helsingin yliopiston suomen kielen opiskelijat. 
valittujen haastattelujen määrä on koottu taulukkoon 3. Aineisto koostuu kolmen ikäryhmän informanteista: noin 20-vuotiaista nuorista, noin 40-vuotiaista keski-ikäisistä ja noin 6o-vuotiaista vanhoista puhujista. Lisäksi 2010-luvun keruussa on haastateltu neljää noin 80-vuotiasta puhujaa, jotka ovat kuuluneet 1990-luvun keruussa 60-vuotiaiden ryhmään. Nämä neljä puhujaa olen laskenut osaksi 2010-luvun vanhojen ryhmää. Pyrin valitsemaan jokaiselta vuosikymmeneltä jokseenkin saman määrän eri-ikäisiä puhujia, mutta ryhmien välillä on kuitenkin pieniä eroja. Vertailen infinitiiviesiintymiä prosentuaalisesti, joten ryhmien kokoerot eivät vaikuta tuloksiin.

Taulukko 3.

Informanttien määrä.

\begin{tabular}{l|c|c|c|c} 
Vuosikymmen & Vanhat (60-v.) & $\begin{array}{c}\text { Keski-ikäiset } \\
(40-\text {-.) }\end{array}$ & Nuoret (20-v.) & Yhteensä \\
\hline 1970-luku & 22 & 20 & 23 & 65 \\
\hline 1990-luku & 13 & 13 & 15 & 41 \\
\hline 2010-luku & $\begin{array}{c}13 \\
(9+4)\end{array}$ & 14 & 17 & 44 \\
\hline Yhteensä & 48 & 47 & 55 & 150 \\
\hline
\end{tabular}

Toinen huomionarvoinen seikka informanttien valinnassa on se, että 1990-luvun ja 2010-luvun vanhojen ja keski-ikäisten ryhmät koostuvat jo aiemmilla kierroksilla haastatelluista informanteista, ja ainoastaan nuorten ryhmät ovat joka kierroksella uusia. Kyseessä on siis trendi- ja paneelitutkimuksen yhdistelmä (esim. Laasanen 2016: 60). Tämä antaa erinomaiset mahdollisuudet näennäisaikahypoteesin (esim. Chambers \& Trudgill 1998: 149-151; Laasanen 2016) tarkasteluun mutta antaa myös pohdittavaa, koska aiemmin haastateltuja informantteja ei ole tutkimuksessa erikseen eritelty joukosta ja tarkasteltu idiolektitasolla.

\section{Infinitiivien variaatio ja muutos}

Tässä luvussa esittelen tutkimuksen keskeiset tulokset. Aloitan tarkastelun infinitiivien kokonaisvariaatiosta diakronisesti (ks. alaluku 3.1). Seuraavaksi (3.2) esittelen $A$ loppuiseen vokaaliyhtymään päättyvien infinitiivimuotojen variaatiota ja muutosta. Lopuksi tarkastelen sananrajailmiöitä (3.3) ja käydä- ja olla-verbien täydennyksiä (3.4).

\subsection{Infinitiivien variaatio ja muutos 1970-luvulta 2010-luvulle}

Vertailuja varten jaoin alaluvussa 2.1 esitellyt infinitiivit kolmeen yleisinfinitiiviin: lyhyisiin infinitiiveihin, A-infinitiiveihin ja illatiivitapauksiin. Lyhyiden infinitiivien joukko koostuu pitkään vokaaliin päättyvistä, useampitavuisista muodoista: antaa,

7. 2010-luvun vanhojen ryhmään kuuluu yhdeksän n. 60-vuotiasta ja neljä n. 80-vuotiasta puhujaa. 
kertoo, lukee, istuu, leikkii, pelaa, parantaa, luistelee. A-infinitiivien ryhmään kuuluvat standardinmukaiset A-infinitiivit (esim. kertoa, lukea, istua, leikkiä, pelata, juosta, saada) ja illatiivitapauksiin puolestaan kaikki muodot, joissa esiintyy joko MA-tunnus tai illatiivin sananloppuinen $n$ (antamaan, antamaa, antaan).

Jotkin tehdyistä valinnoista ovat tulkinnanvaraisia ja vaativat siksi perusteluja. Antaa-tyyppi on laskettu lyhyisiin infinitiiveihin, vaikka se on standardinmukainen Ainfinitiivi. Se vastaa kuitenkin muodoltaan lyhyttä infinitiiviä, ja sen mallivaikutus voidaan nähdä esimerkiksi Helsingin puhekielen supistumaverbeissä (Itkonen 1964); vastaava analogia koskee esimerkiksi partitiiveja (alaluku 3.2; Paunonen 1995 [1982]: 126). Toisekseen on syytä palata sananloppuisen $n$-äänteen käyttäytymiseen sananrajalla (ks. alalukua 2.1). Nyt tehdyllä jaottelulla esimerkiksi seuraavat kuvitteelliset tapaukset asettuvat kyseenalaisiksi:
(a) Mennään pelaamaan niille.
(b) Mennään pelaan niille.
(c) Mennään pelaa.

Näistä c-kohdan lyhyt infinitiivi voi selittyä sen asemalla absoluuttisessa lopussa, kun taas b-kohdan pelaan-muodossa nasaalia edeltävä $n$ voidaan nähdä joko assimilaatioilmiönä tai illatiivin päätteenä. Mikäli c-kohdan pelaa ei olisikaan absoluuttisessa lopussa, vaan sitä seuraisi esimerkiksi nasaali tai klusiili, se voisi käyttäytyä täysin b:n tavoin. On selvää, että näistä esimerkki b on muodoltaan läheisempi esimerkin c kuin esimerkin a kanssa, mutta edellä esitellyssä jaottelussa b päätyykin samaan ryhmään MAtunnuksellisen illatiivin kanssa (a). Olen kuitenkin päätynyt edellä esitettyyn jaotteluun siitä syystä, että pääte - $V V n$ on muodoltaan selvästi illatiivi, vaikka siinä ei olisikaan MAtunnusta. Tästä syystä en kuitenkaan käytä nimitystä MA-infinitiivin illatiivi, vaan puhun yleisemmin illatiiveista (vaikka joukkoon mahtuu toki tapauksia, joissa on MAtunnus eikä vuorostaan kokonaista illatiivin tunnusta). MA-tunnuksettomien illatiivimuotojen (antaan) osuus koko aineistosta on noin 1,8 \%, joten niiden lajittelun vaikutus on lopulta vähäinen.

Infinitiivien kokonaisvariaatio esiteltyjen kolmen infinitiivin osalta kaikilla vuosikymmenillä ja kaikissa ikäryhmissä on esitetty kuviossa 1 (ks. seur. sivu). Olen poiminut kaikilta vuosikymmeniltä yhteensä 10057 infinitiiviesiintymää, joita vertailen tässä luvussa prosentuaalisesti. Kuviosta 1 voidaan havaita muutama hyvin selvä tendenssi. Lyhyt infinitiivi on jokaisella vuosikymmenellä yleisin infinitiivimuoto nuorten puheessa. Vastaavasti illatiivimuodot vähenevät jokaisella vuosikymmenellä vanhemmista nuorempiin siirryttäessä. Eri ikäryhmien välillä on kaikilla vuosikymmenillä ja kaikissa infinitiivimuodoissa tilastollisesti erittäin merkitseviä eroja $(\mathrm{p}<0,001) .{ }^{8}$ Vaikka erot ovat merkitseviä kaikissa infinitiivimuodoissa, suurimmat ne ovat vertailtaessa lyhyttä infinitiiviä muihin infinitiivimuotoihin ja toiseksi suurimmat illatiivissa. Ikäsidonnainen muutos (ks.

8. Khiin neliö -testin mukaan lyhyen infinitiivin ja muiden infinitiivimuotojen välillä on erittäin merkitseviä eroja kaikkia kolmea ikäryhmää vertailtaessa $(2(2)=251,79, p<0,001)$. A-infinitiivin osalta lukemat ovat $2(2)=60,20, p<0,001$ ja illatiivin osalta $2(2)=108,18, p<0,001$. 
alalukua 2.2) näyttääkin koskettavan juuri näitä kahta infinitiivimuotoa. A-infinitiivin osalta erot ovat pienempiä, joskin silti tilastollisesti merkitseviä. Tämä on odotuksenmukainen tulos, koska kuten alaluvussa 2.1 totesin, $d A$-verbit ja konsonanttivartaloiset verbit eivät todennäköisesti voi lyhentyä. Kun nämä verbit kuitenkin kattavat huomattavan osan kaikista infinitiiviesiintymistä (noin 30 \%), jää muutokselle vähemmän tilaa. Ainfinitiiveissä tapahtuvia muutoksia käsittelen alaluvussa 3.2.

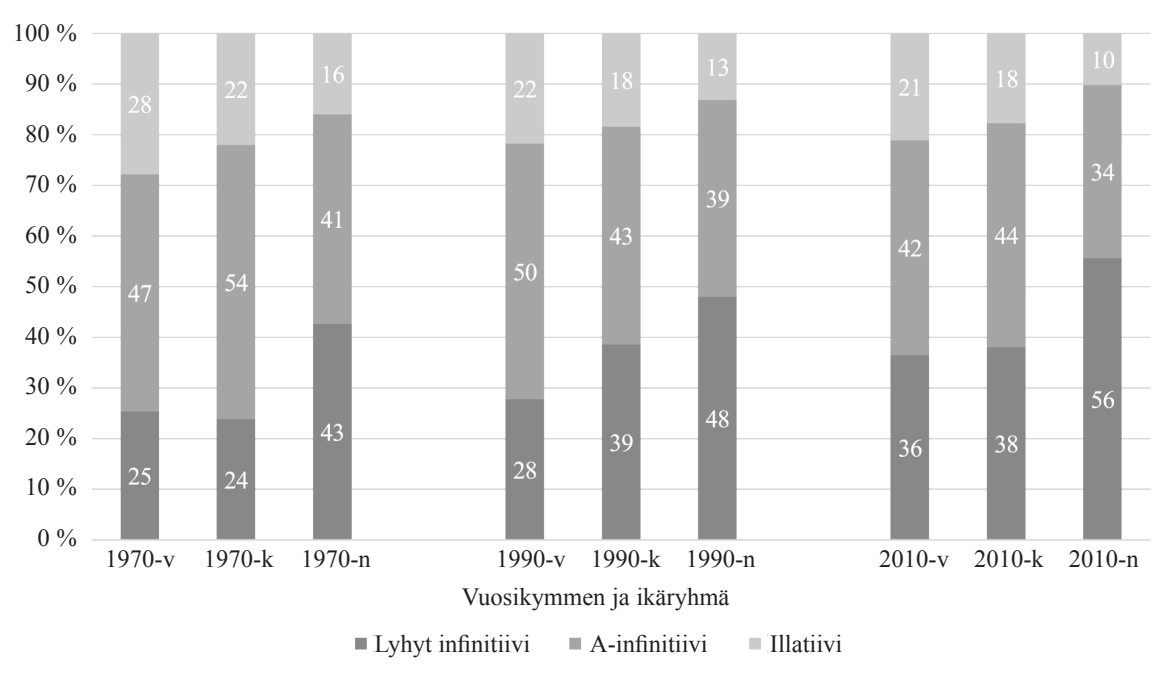

Kuvio 1.

Infinitiivien kokonaisvariaatio.

Kun vertaillaan ikäryhmiä portaittain, huomataan, että erot ovat selvimmät nuorten ja keski-ikäisten välillä. Kaikissa infinitiivimuodoissa erot nuorten ja keski-ikäisten välillä ovat khiin neliö -testin mukaan tilastollisesti erittäin merkitseviä $(\mathrm{p}<0,001) .{ }^{9}$ Sen sijaan vanhojen ja keski-ikäisten välillä erot esimerkiksi A-infinitiiviesiintymissä eivät ole merkitseviä $\left(\mathrm{X}^{2}(1)=0,19, \mathrm{p}=0,660\right)$, vaikka muissa infinitiivimuodoissa on näidenkin kahden ikäryhmän välillä merkitseviä eroja. Tämä antaa lisätukea sille jo kuviosta 1 silmämääräisesti tehtävälle havainnolle, että infinitiivimuotojen käyttö on osittain hyvinkin ikäsidonnaista. Toisekseen tilastolliset erot kertovat siitä, että A-infinitiivi on infinitiivimuodoista vähiten altis ikäkauteen liittyvälle muutokselle.

Esittelen infinitiivien muutosmalleja seuraamalla aineiston jokaisessa vaiheessa mukana ollutta sukupolvea vuosikymmeneltä toiselle. 1970-luvun nuoret, 1990-luvun keski-ikäiset ja 2010-luvun vanhat edustavat samaa joukkoa (lukuun ottamatta neljää 2010-luvun vanhojen joukkoon laskettua jo 8o-vuotiasta informanttia). Tätä joukkoa tarkasteltaessa huomataan, että sukupolvi tuntuu pitävän yllä nuorena aloitettua ten-

9. Keski-ikäisten ja nuorten väliset erot lyhyessä infinitiivissä khiin neliö -testin mukaan: $2(1)=134,93$, $p<0,001$. A-infinitiivissä: $2(1)=47,59, p<0,001$ ja illatiivissa: $2(1)=38,84, p<0,001$. Vanhojen ja keskiikäisten väliset erot puolestaan ovat lyhyessä infinitiivissä merkitseviä $2(1)=10,04, p=0,002$ ja illatiivissa erittäin merkitseviä $2(1)=16,61, p<0,001$. 
denssiä (sukupolvittainen muutos), mutta lyhyen infinitiivimuodon määrät vähenevät ja illatiivimuotojen puolestaan kasvavat vuosikymmeneltä toiselle (ikäsidonnainen muutos). Voidaan siis todeta, että lyhyen infinitiivin yleisyys on osittain ikäsidonnaista mutta muutos on kuitenkin selvästi myös sukupolvittaista (ks. alalukua 2.2; Kurki 2013: 206-210). Olennaista on myös huomata, että illatiivi ja lyhyt infinitiivi ovat Ainfinitiiviä selvemmin ikäsidonnaisia. Näin ollen lyhyt infinitiivi MA-infinitiivin illatiivin tehtävissä on nuorille leimallinen piirre, kun taas lyhyt infinitiivi A-infinitiivin tehtävissä on selvemmin yleisesti hyväksytty eikä leimaudu tiettyyn ryhmään (leimautuneista piirteistä ks. Mantila 2004). Tällä voi olla huomattavia vaikutuksia muodon yleistymiseen, mihin palaan alaluvussa 4.2.

Lyhyt infinitiivi on siis leimallisesti nuorten infinitiivimuoto, mutta se säilyy heidän puheessaan jossain määrin myös myöhemmillä vuosikymmenillä eikä väisty täysin ikääntymisen myötä. Sen sijaan Sankoffin (2005) esittämää elinikäistä muutosta, jossa vanhemmat ikäryhmät ikään kuin hyppäävät muutokseen mukaan, ei infinitiivimuodoissa juuri näytä tapahtuvan, vaan vanhemmiten muutoksen suunta on ennemminkin nuorten suosimasta muodosta poispäin - erityisesti siis MA-infinitiivin illatiivin tehtävissä. Tästä huolimatta lyhyt infinitiivi yleistyy vuosikymmeneltä toiselle, mitä voidaan havainnollistaa laskemalla kaikkien ikäryhmien esiintymämäärät yhteen ja vertailemalla vuosikymmenkohtaisia määriä (kuvio 2).

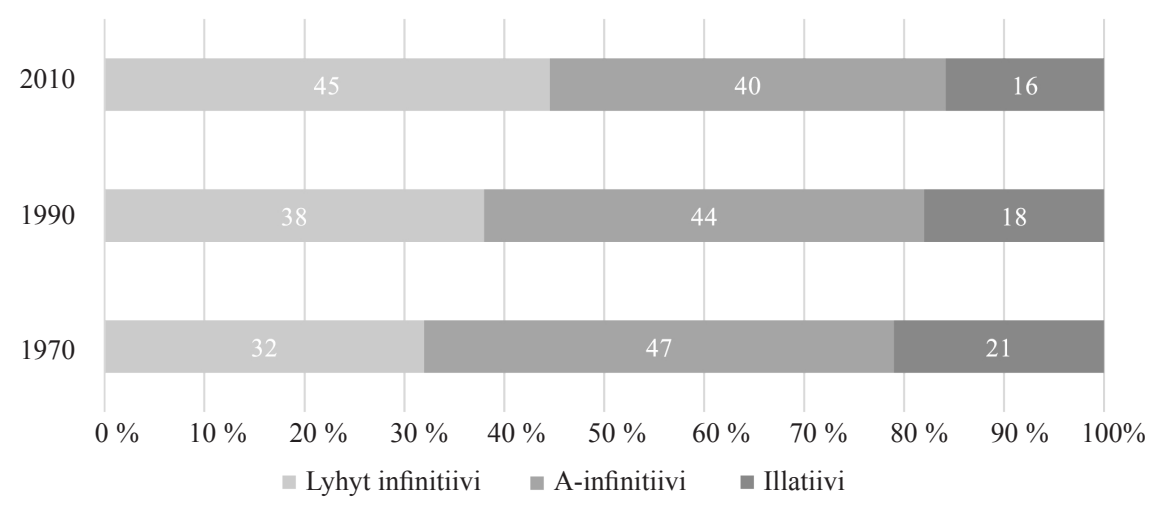

Kuvio 2.

Vuosikymmenkohtainen vertailu.

Kuviosta 2 havaitaan, että infinitiivien välillä tapahtuu muutosta myös vuosikymmenittäin. Lyhyt infinitiivi yleistyy jokaisella vuosikymmenellä kahden muun kustannuksella. Erot vuosikymmenten välillä ovat tilastollisesti erittäin merkitseviä ( $\mathrm{p}<\mathrm{0,001)}$, ja suurimmat erot löytyvät jälleen vertailtaessa lyhyttä infinitiiviä muihin infinitiivimuotoihin. ${ }^{10}$ Näin ollen myös yhteisön kielenkäyttö muuttuu selvästi vuosikymmeneltä toiselle siirryttäessä eikä muutos jää ikäsidonnaiseksi. 2010-luvun

10. Verrattaessa lyhyttä infinitiiviä muihin infinitiivimuotoihin vuosikymmenten välillä erot ovat khiin neliö -testin mukaan erittäin merkitseviä $(2(2)=99,14, p<0,001)$. Samoin A-infinitiivissä $(2(2)=$ $27,77, \mathrm{p}<0,001)$ ja illatiivissa $(2(2)=33,14, \mathrm{p}<0,001)$ erot ovat tilastollisesti erittäin merkitseviä. 
aineistossa lyhyt infinitiivi on kaikkein yleisin variantti, mutta jo 1970-luvun aineistossa lyhyitä infinitiivimuotoja on huomattavan suuri määrä. Tätä selittää etenkin se, että antaa-tyyppi on laskettu lyhyiden infinitiivien joukkoon. Vastaavasti $A$-loppuisten vokaaliyhtymien assimilaatio (kertoa $>$ kertoo) on jo vanha ilmiö. Suurin osa lyhyistä infinitiiveistä on vielä 2010-luvullakin A-infinitiivilähtöisiä, ja tarkastelen niitä seuraavaksi. Itse puhetilanteen kannalta lähtöinfinitiivi on sinänsä yhdentekevä, mutta sen tarkastelu kertoo muutoksen lähtökohdista ja suunnasta.

\subsection{A-loppuiseen vokaaliyhtymään päättyvien infinitiivimuotojen muutos}

Edellisessä luvussa totesin, että A-infinitiiviesiintymissä erot eri ikäryhmien ja vuosikymmenten välillä eivät ole yhtä merkittäviä kuin kahdessa muussa infinitiivimuodossa. Tätä selitin sillä, että osa A-infinitiiveistä ei voi lyhentyä. Suurin osa lyhyistä infinitiiveistä toimii kuitenkin nimenomaan A-infinitiivin tehtävissä, ja ne syntyvät ennen kaikkea $A$-loppuiseen vokaaliyhtymään päättyvien infinitiivimuotojen assimilaation kautta. Näitä esittelen kuviossa 3.

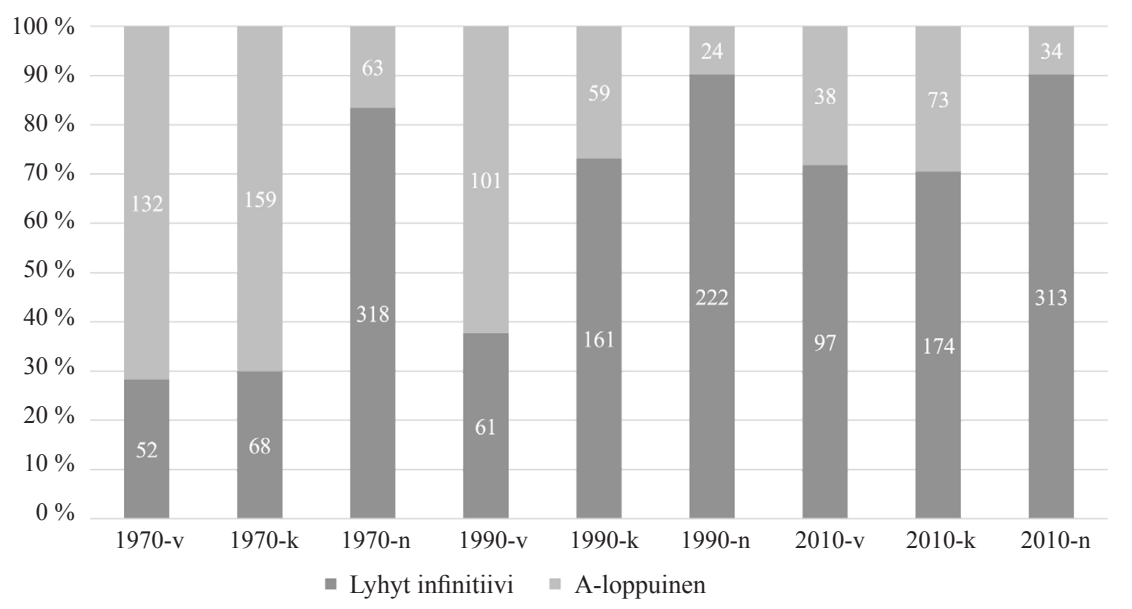

Kuvio 3.

A-loppuisen vokaaliyhtymän esiintymät prosentuaalisesti ja määrällisesti.

Kuviosta 3 huomataan, että myös $A$-loppuisen vokaaliyhtymän sisältävissä tapauksissa nuoret käyttävät huomattavan paljon enemmän lyhyitä infinitiivejä kuin niiden standardinmukaisia vastineita. Toinen olennainen huomio on se, että muutos on jälleen selvästi sukupolvittaista: sama puhujajoukko (1970-luvun nuoret, 1990-luvun keskiikäiset ja 2010-luvun vanhat) pitää kiinni lyhyestä infinitiivistä. Toisaalta muutos on myös ikäsidonnaista: varianttien väliset erot kaventuvat ryhmän sisällä puhujien vanhetessa. Näin ollen voidaan tässäkin yhteydessä todeta näennäisaikahypoteesin olevan oikeansuuntainen mutta ikäsidonnaisen muutoksen hidastavan sukupolvittaista muutosta (vrt. Laasanen 2016).

$A$-loppuiseen vokaaliyhtymään päättyvien verbien osalta erot ovat khiin neliö -testin mukaan erittäin merkitseviä vuosikymmenien välillä $\left(\mathrm{X}^{2}(2)=110,26, \mathrm{p}<0,001\right)$. Muoto- 
ryhmiä erikseen tarkasteltaessa vain $i A$-loppuisissa verbeissä (esim. leikkiä) ei ole khiin neliö -testin mukaan tilastollisesti merkitseviä eroja. Tämä noudattelee $A$-loppuisten vokaaliyhtymien assimilaatiosta jo vanhastaan tiedettyä kaavaa: kuten olen jo edellä tuonut esiin, $e A$ ja $O A$ assimiloituvat herkemmin kuin $U A$ ja $i A$ (esim. Paunonen 1995 [1982]: 107-109). Korpuksen 1970-luvun aineistoa käsittelevässä tutkimuksessaan Paunonen toteaa, että $i A$-yhtymä assimiloituu kaikissa muotoryhmissä vain kolmasosassa tapauksista. Nuorten esiintymiin nojaten hän kuitenkin ounastelee erojen kaventuvan (mts. 110-113). Tässä tutkimuksessa ero onkin infinitiivien osalta selvästi kaventunut, sillä 2010-luvun aineistossa pitkävokaaliset muodot (pitää leikkii) ovat niukassa enemmistössä. iA-loppuisten infinitiivien esiintymämäärä on kuitenkin kovin vähäinen, joten niitä ei voi suoraan vertailla Paunosen tarkastelemiin huomattavan frekventteihin partitiivimuotoihin.

Paunonen esittää (mts. 126), että partitiivimuodoissa $A$-loppuisen vokaaliyhtymän variaatio on lopulta johtanut partitiivin muodostussäännön muutokseen: alkuperäinen sääntö (vartalo $+A$ ) on korvautunut säännöllä vartalo + vartalovokaalin pidennys. Malliksi tälle muutokselle Paunonen esittää jo valmiiksi A-loppuisia sanoja: kalaa, kesää > ovee, taloo, tuntii, lintuu. Vastaavanlainen analogia vaikuttaa myös infinitiivimuotojen taustalla, ja ylipäänsä kaksitavuinen, pitkään vokaaliin päättyvä sanahahmo esiintyy Helsingin puhekielessä monissa eri muotoryhmissä. Tähän palaan alaluvussa 4.2.

\subsection{Sananrajailmiöt lyhyessä infinitiivissä}

Kun tarkastellaan infinitiivien järjestelmää, on syytä huomioida myös sanojen rajoilla tapahtuvat ilmiöt. A-infinitiivin latiivisija esiintyy nykysuomessa jäännöslopukkeena ja on yksi voimakkaimmin rajageminaatiota toteuttavista muotoryhmistä (VISK $\$ 34$; Karlsson \& Lehtonen 1977: 10-15). MA-infinitiivin illatiivin loppu- $n$ sen sijaan assimiloituu sitä seuraavien konsonanttien laadusta riippuen hieman eri tavoin. Samalla tavalla illatiivi ja latiivi käyttäytyvät kuitenkin $l: n, r: n, j: n$ ja $v: n$ edellä: mennään pelaal lätkää vrt. voidaan pelaal lätkää. Sananrajalla tapahtuvat ilmiöt kertovatkin siitä, mihin muotoihin lyhyt infinitiivi kiinnittyy: toteuttaako se $k$ :n sandhikaavaa (kuten Ainfinitiivin latiivi), n:n sandhikaavaa (kuten illatiivi) vai ei mitään (kuten yksikön kolmannen persoonan muoto)?

Tätä selvittääkseni jaoin sananrajailmiöt kolmeen ryhmään: Ensin poistin joukosta lausumanloppuiset ja vokaalia edeltävät tapaukset, koska niissä rajailmiöitä ei esiinny. ${ }^{11}$ Loput tapaukset jaottelin sen mukaan, tapahtuuko sananrajalla assimilaatioilmiöitä vai ei; rajageminaatio- ja assimilaatiotapaukset on siis yhdistetty. Ongelmia erotteluun tuottaa se, että eri vuosikymmenten haastattelut on litteroitu erilaisella tarkkuudella (Paunonen, henkilökohtainen tiedonanto 19.5.2017). 1970-luvulla ja 2010-luvulla rajageminaatioiden merkinnässä on suurta horjuntaa (tai siitä on luovuttu kokonaan), kun taas 1990-luvulla merkinnät ovat huomattavan tarkkoja. Niinpä olen tarkistanut kuuntelemalla joitakin epäselviä kohtia tämän tutkimuksen tarpeisiin.

11. Vokaalien edellä rajageminaatio voi toteutua glottaaliklusiilina, mutta sen esiintyminen on huomattavasti horjuvampaa kuin konsonanttien kahdentumisen (Karlsson \& Lehtonen 1977: 16). 
Tutkimus osoittaa, että A-infinitiivitapauksissa rajageminaatio toteutuu melko järjestelmällisesti kaikissa ikäryhmissä ja kaikilla vuosikymmenillä. MA-infinitiiviesiintymissä sen sijaan assimiloitumattomat tapaukset ovat niukassa enemmistössä kaikilla vuosikymmenillä. Vastaavat erot näkyvät myös lyhyen infinitiivin sananrajailmiöissä: Ainfinitiivilähtöisissä lyhyissä infinitiivimuodoissa rajageminaatio toteutuu $70-80$ prosentissa tapauksista (voi pelaal lätkää), kun MA-infinitiivilähtöisten kohdalla on enemmän horjuntaa. Nuorten puheessa MA-infinitiivilähtöisissä muodoissa on 1970-luvulla lähes saman verran assimilaatiotapauksia (mennään pelaal lätkää) kuin assimiloitumattomia (mennään pelaa lätkää). 1990- ja 2010-luvulla nuorten puheessa assimilaatiotapauksia on jo enemmistö. Ikäsidonnaisuus näyttääkin vaikuttavan myös MA-infinitiivilähtöisen lyhyen infinitiivimuodon käyttäytymiseen sananrajalla, sillä keski-ikäisten ja vanhojen puheessa assimiloitumattomat muodot ovat enemmistössä. MA-infinitiivilähtöisen lyhyen infinitiivin esiintymämäärät sananrajalla ovat kuitenkin keski-ikäisten ja vanhojen ryhmissä selvästi pienemmät kuin nuorilla, mikä vaikeuttaa uskottavaa vertailua. Lisäksi on muistettava, että sananrajailmiöissä on paljon variaatiota niin idiolektitasolla kuin erilaisissa äänneympäristöissä (Karlsson \& Lehtonen 1977: 15), minkä takia ryhmätason vertailut ovat lähinnä suuntaa antavia. Havaintojen perusteella voidaan todeta, että lyhyt infinitiivi ei ole ainakaan vielä sananrajalla vakiintunut tiettyyn muotoon, vaan se noudattaa lähtöinfinitiivien sandhikaavoja. Orastavaa ikäsidonnaisuutta on kuitenkin havaittavissa siinä, että nuorten puheessa MA-infinitiivilähtöinen lyhyt infinitiivi vaikuttaa assimiloituvan herkemmin kuin vanhojen tai keski-ikäisten puheessa.

\section{4 käydä- ja olla-verbien täydennykset}

Lyhyen infinitiivin muotoja esiintyy jonkin verran myös käydä- ja olla-verbien täydennyksinä tilanteissa, joissa yleiskielessä käytettäisiin inessiiviä: kävin pelaa < kävin pelaamassa. Myös MA-tunnuksettomia illatiivi- ja inessiivimuotoja (käydä pelaan pelaas) tavataan murteissa. Näiden verbien täydennysten alueellista variaatiota ja taustaa on esitellyt Ylikoski (2005).

Tämän tutkimuksen aineiston esiintymämäärät ovat näiden verbien täydennysten osalta hyvin vähäisiä, enkä siksi käsittele niitä tilastollisesti. Suurin osa aineiston täydennyksistä on kaikilla vuosikymmenillä inessiivimuotoja tai niiden loppuheittoisia variantteja (käydä pelaamas). Aineistosta voidaan kuitenkin havaita, että 2010-luvun nuorten puheessa lyhyet infinitiivimuodot ovat melko yleisiä myös käydä- ja ollaverbien täydennyksinä (10/45 esiintymää). Huomattavaksi määrän tekee se, että esimerkiksi 1970-luvun nuorilla esiintymiä on vain kaksi kaikkiaan hieman alle sadasta esiintymästä (2/97) ja vielä 1990-luvun nuorillakin vain vajaa kymmenesosa (5/54). Näin ollen voidaan suuntaa antavasti todeta, että lyhyt infinitiivi käydä- ja olla-verbien täydennyksenä vaikuttaa olevan vasta yleistymässä Helsingin puhekielessä.

\subsection{Kokoavasti tuloksista}

Tässä luvussa olen esitellyt tutkimuksen keskeiset tulokset infinitiivien kokonaisvariaation osalta ja eritellyt myös muutoksen taustalla olevia syitä. Tärkeimpänä havain- 
tona esitin, että lyhyt infinitiivi yleistyy vuosikymmeneltä toiselle ja se on 2010-luvulla jo kaikkein yleisin infinitiivimuoto. Lisäksi kiinnostavaa on se, että sekä lyhyt infinitiivi että illatiivimuoto vaikuttavat edustavan niin sanottua ikäsidonnaista muutosta: lyhyt infinitiivi on erityisesti nuorten suosima muoto, kun taas illatiivi vanhempien puhujien. Pelkällä ikäsidonnaisuudella eroja ei kuitenkaan voi selittää, sillä lyhyt infinitiivi yleistyy myös vuosikymmeneltä toiselle sukupolvittaisen muutoksen myötä, eli puhujat eivät täysin luovu tästä variantista ikääntyessään. Lyhyen infinitiivin yleistyminen kiinnittyy ennen kaikkea MA-infinitiivin illatiivimuotojen lyhentymiseen (meen kertoo) ja $A$-loppuiseen vokaaliyhtymään päättyvien muotojen assimiloitumiseen (voin kertoo). Assimilaatiotapauksissa on havaittavissa eroja eri vokaaliyhtymien välillä: $i A$ yhdistelmä assimiloituu hitaammin kuin muut yhdistelmät. Vastaava tendenssi on havaittu myös partitiivimuotojen tutkimuksessa (Paunonen 1995 [1982]: 122-132).

Muodollisesti lyhyt infinitiivi ei ole vielä vakiintunut tietynlaiseksi, vaan se kiinnittyy yhä pitkälti lähtöinfinitiiveihinsä: A-infinitiivilähtöiset lyhyet infinitiivimuodot toteuttavat loppukahdennusta, kun taas MA-infinitiivilähtöisissä varianteissa loppu- $n$ ei yhtä voimakkaasti assimiloidu seuraavaan äänteeseen. Tässä suhteessa lyhyen infinitiivin sisäinen variaatio on vielä suurta, ja myöhempien tutkimusten näytettäväksi jää, kieliopillistuuko lyhyt infinitiivi tiettyyn muotoon ja merkitykseen vai jääkö se nykyiselleen - kahden tulosijaisen infinitiivimuodon kontaminaatioksi.

\section{Infinitiivijärjestelmä muutoksessa}

Tässä luvussa esittelen infinitiivijärjestelmän nykytilannetta Helsingin puhekielessä. Tarkastelu on siis ennen kaikkea synkronista ja pohjautuu edellisessä luvussa esittelemiini muutoksiin. Luon myös katseen tulevaisuuteen ja pohdin muutostendenssejä.

\subsection{Kolme infinitiiviä - morfologiset ja semanttiset erot}

Olen edellä osoittanut aiemmissa tutkimuksissa (esim. Sorsakivi 1982; Paunonen 1995 [1982]) ounasteltujen muutosten edenneen melko pitkälle. Lyhyt infinitiivi on yleistynyt vuosikymmeneltä toiselle, ja 2010-luvun aineistossa se on jo kaikkein yleisin infinitiivimuoto. Muodon synnyn ja yleistymisen taustalla vaikuttavat ennen kaikkea muutamat äänteenmuutokset, jotka ovat ajaneet infinitiivimuodot yhteen. Toisaalta muotojen päädyttyä yhteiseen asuun analoginen mallivaikutus on entuudestaan lisännyt muodon yleisyyttä. Systemaattiset äänteenmuutokset ovat siis luoneet infinitiivijärjestelmään kaoottisuutta, jota analogia on vuorostaan systematisoinut (Sturtevant 1917: 108-109; Anttila 1989: 94). Voidaan kuitenkin puhua vain osittaisesta produktiivisuudesta, sillä analogia ei ainakaan vielä toistaiseksi yllä $d A$-verbeihin ( ${ }^{*}$ pitää syö) tai konsonanttivartaloisten verbien A-infinitiivimuotoihin ( ${ }^{*}$ pitää tulee). Näiden verbimuotojen muutosmahdollisuuksia käsittelen alaluvussa 4.2.

Kolmen (yleis)infinitiivin järjestelmässä on paljon päällekkäisyyttä: eri infinitiivit eroavat toisistaan lähinnä muodoltaan, ja merkityserot ovat vähäisempiä. Infinitiivien merkityksien eroja esittelen konstruktioina kuviossa 4. 
Kuparinen Infinitiivien variaatio ja muutos Helsingissä

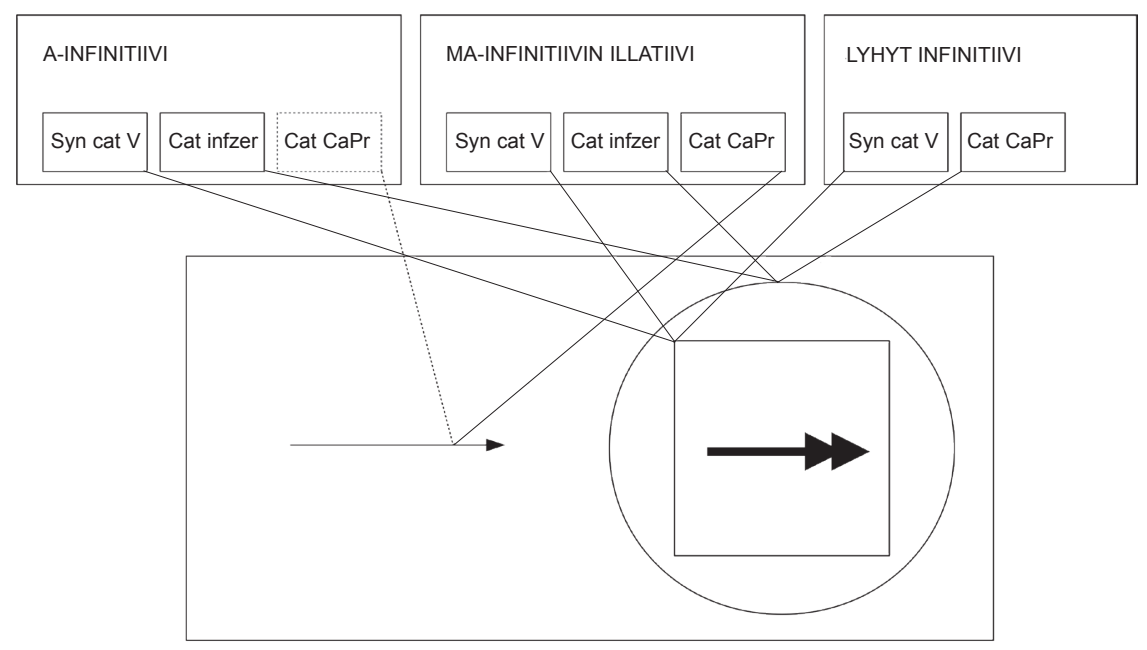

Kuvio 4.

Infinitiivien merkityksenkuvaus (Leino 2003: 105 mallina; Kuparinen 2015: 72).

Kuviossa 4 olen yhdistänyt konstruktiokuvaukset merkityksenkuvaukseen. Kuvaus on hyvin abstrakti eikä välttämättä kovin informatiivinen. Siitä voidaan kuitenkin erottaa infinitiivien välisiä eroja. MA-infinitiivin illatiivi täyttää kaikki kolme kuvauksen kohteena olevaa ominaisuutta: sillä on verbivartalo (V), infinitiivin tunnus (infzer) ja sijapääte (CaPr). A-infinitiivin sijapääte on hälvennyt ja esiintyy nykyään jäännöslopukkeena. Näin ollen olen merkinnyt sen kuvaan katkoviivalla. Lyhyessä infinitiivissä en katso olevan sijaa lainkaan, vaan se koostuu pelkästään verbivartalosta ja infinitiivin tunnuksesta, joka lyhyessä infinitiivissä on vartalovokaalin pidennys. Lyhyt infinitiivi siis erkaantuu infinitiivien sijajärjestelmästä ja lähestyy puhdasta deverbaaliutta. Näin ollen infinitiivijärjestelmässä voisi olla tapahtumassa muutos kohti yhden yleisinfinitiivin järjestelmää indoeurooppalaisten kielten - tai pohjoissaamen - tapaan.

Myönnän, että kuvio 4 on pitkälti idealisoitu kuvaus infinitiivien järjestelmästä, joka on jatkuvasti jäsentyvä. Alaluvussa 3.3 huomautin, että lyhyt infinitiivi ei ole vielä muodollisesti erkaantunut lähtöinfinitiiveistään, vaan se toteuttaa esimerkiksi loppukahdennusta lähtöinfinitiivinsä mukaan. Voitaisiinkin esittää ajatus, että lyhyt infinitiivi on vain yksi variantti sekä A-infinitiivistä että MA-infinitiivin illatiivista. ${ }^{12}$ Tämä variantti vain sattuu olemaan samanlainen molemmissa tapauksissa. Muotojen samuus vaikuttaa kuitenkin huomattavalla tavalla niiden tulkintaan. Onkin jok-

12. Tämä on pitkälti ollutkin tapana fennistisessä variaationtutkimuksessa: lyhyen infinitiivin muodot eivät ole mitenkään uusia puhekielessä, mutta niiden näkymättömyys alan kirjallisuudessa johtuu ennen kaikkea siitä, että ne on tulkittu eri tavoin: MA-infinitiivilähtöiset tapaukset MA-tunnuksettomiksi illatiiveiksi ja A-infinitiivilähtöiset tapaukset A-infinitiiveiksi, joissa on tapahtunut erilaisia äänteenmuutoksia. Tämä on osaltaan seurausta suomalaisen puhekielen tutkimuksen kiinnittymisestä tiettyihin äänne- ja muotopiirteisiin (vrt. Nuolijärvi \& Sorjonen 2005: 130-136). 
seenkin selvää, että nykyisellään lyhyt infinitiivi leviää ennen kaikkea analogian voimin: infinitiiviä merkitään Helsingin puhekielessä vartalovokaalin pidennyksellä. Tätä kieliopillistumispolkua ja analogiaa käsittelen tarkemmin seuraavassa alaluvussa.

Infinitiivien merkityseroja on sanomalehtitekstien osalta tarkastellut Herlin (2012). Tutkimuksessaan hän vertailee A-infinitiiviä ja MA-infinitiivin illatiivia alkaa-verbin täydennyksenä ja esittää, että verbin merkityksen ohella myös kuvatun alkamisprosessin luonne ohjaa infinitiivin valintaa (ks. myös englannista Wierzbicka 1988: 85-87). Tätä edesauttaa se, että alkaa on merkitykseltään jokseenkin väljä (Herlin mts. 149). Alkaa tarjoaakin hyvän mahdollisuuden myös tämän tutkimuksen aineiston infinitiivien merkityserojen tarkasteluun, koska se voi saada täydennyksekseen minkä vain infinitiivimuodoista. Näin voidaan selvittää, onko infinitiivien merkityksessä kenties jotakin sellaista, joka edesauttaa tai estää infinitiivien sekoittumista ja leviämistä. Herlinin (mts. 162-170) mukaan MA-infinitiivin illatiivin esiintymistä alkaa-verbin täydennyksenä edesauttavat

a) prosessin pitkäkestoisuus ja vähittäisyyden ilmaukset

b) preesens aikamuotona

c) epäspesifi tekijä ja

d) prosessin dynaamisuus.

Lisäksi Herlin nostaa esiin erityisesti frekventatiivien johdosluokan, joka tuntuu herkästi esiintyvän MA-infinitiivin illatiivissa.

Tarkastelen tässä lyhyesti aineiston litteroiduista haastatteluista alkaa-verbin infinitiivitäydennyksiä suhteuttamalla niitä Herlinin tarjoamiin selittäviin tekijöihin. Käytän apuna logistisen regression mallia, jossa selittäviin tekijöihin nojaten voidaan arvioida kategoristen muuttujien todennäköisyyksiä (Cox 1958). Malli antaa siis mahdollisuuden laskea, miten eri tekijät vaikuttavat infinitiivimuotojen todennäköisyyksiin. On huomioitava, että selittävien tekijöiden arvioiminen on tässä tapauksessa jokseenkin tulkinnanvaraista: esimerkiksi prosessien pitkäkestoisuudessa on useita tasoja, joiden luokitus saattaa olla ajoittain hankalaa.

Aineistossani on kaikkiaan 158 alkaa-verbin täydennyksenä toimivaa infinitiiviä, ja ne jakautuvat hyvinkin tasan eri varianttien kesken: A-infinitiivitapauksia on 57, illatiivitapauksia 51 ja lyhyttä infinitiiviä 50 . Taulukossa 4 (seur. sivulla) on esitetty logistisen regression tuottamat vetosuhteet (engl. odds ratio, 'todennäköisyyksien suhde'), kun illatiivimuotoja ja lyhyitä infinitiivejä on verrattu A-infinitiiviin. Näin ollen tilanteessa, jossa vetosuhde on suurempi kuin yksi, kyseinen infinitiivimuoto on todennäköisempi kuin A-infinitiivi vastaavassa tehtävässä. Vastaavasti arvot alle yhden tarkoittavat infinitiivimuodon olevan vähemmän todennäköinen. Esimerkiksi tässä aineistossa preesens-muotoiset alkaa-verbit saavat todennäköisemmin illatiivitäydennyksen kuin A-infinitiivin (vetosuhde 1,32), kun taas perfektissä tilanne on päinvastainen (o,38).

Koska aineisto on melko pieni ja joitakin selittäviä tekijöitä esiintyy aineistossa kovin vähän, käytän tulosten esittämisessä lisäksi luottamusväliä. Luottamusvälillä tarkoitetaan sellaista kahden arvon väliä, jonka voidaan valitun luottamustason (tässä tapauksessa $95 \%$ ) varmuudella sanoa sisältävän oikean arvon. Luottamusväli siis ottaa 
huomioon aineiston koon ja hajonnan. Esimerkiksi vähittäisyyden ilmauksia on aineistossa niin vähän, että niiden luottamusväli kasvaa huomattavan suureksi. Mikäli vetosuhteiden luottamusväli on kokonaisuudessaan yli yhden, voidaan todeta 95 prosentin varmuudella positiivinen yhteys - mikäli alle yhden, yhteys on negatiivinen. Jos luku yksi (1) sisältyy luottamusväliin, yhteyttä ei voida tällä varmuudella todentaa.

\section{Taulukko 4.}

alkaa-verbin täydennysten selittävien tekijöiden vetosuhteet ja luottamusvälit.

\begin{tabular}{l|c|c|c|c} 
Muuttuja & $\begin{array}{l}\text { Illatiivi } \\
\text { Vetosuhde }\end{array}$ & $\begin{array}{l}\text { Illatiivi } \\
\text { Luottamusväli 95\% }\end{array}$ & $\begin{array}{l}\text { Lyhyt infinitiivi } \\
\text { Vetosuhde }\end{array}$ & $\begin{array}{l}\text { Lyhyt infinitiivi } \\
\text { Luottamusväli 95 \% }\end{array}$ \\
\hline Preesens & 1,32 & $0,58-3,04$ & 1,16 & $0,48-2,78$ \\
\hline Perfekti & 0,38 & $0,06-2,33$ & 1,80 & $0,43-7,46$ \\
\hline Pitkäkestoinen & 1,92 & $0,82-4,49$ & 2,24 & $0,96-5,20$ \\
\hline Frekventatiivi & 1,96 & $0,48-7,97$ & 0,14 & $0,01-1,46$ \\
\hline Epäspesifi & 0,54 & $0,23-1,27$ & 0,44 & $0,18-1,08$ \\
\hline Dynaaminen & 1,19 & $0,52-2,73$ & 0,48 & $0,19-1,24$ \\
\hline Vähittäinen & 1,68 & $0,32-8,82$ & 3,61 & $0,79-16,58$ \\
\hline
\end{tabular}

Jos tarkastellaan taulukosta 4 vain aineistossa esiintyviä vetosuhteita, Herlinin esittämät selittävät tekijät näyttävät uskottavilta: illatiivissa preesens, pitkäkestoisuus, frekventatiivisuus, dynaamisuus ja vähittäisyys saavat kaikki yli yhden meneviä arvoja, eli A-infinitiiviin verrattuna illatiivin todennäköisyys on suurempi. Vain epäspesifin tekijän vetosuhde jää alle yhden, mikä on vastoin aiempaa hypoteesia. Lyhyt infinitiivi saa illatiivin tavoin suuremman todennäköisyyden A-infinitiiviin verrattuna preesensissä, pitkäkestoisuudessa ja vähittäisyydessä, mutta poikkeaa illatiivista frekventatiivien ja dynaamisuuden alhaisissa todennäköisyyksissä. Erityisesti frekventatiivien osalta ero on merkittävä: frekventatiiviverbi esiintyy lyhyenä infinitiivinä aineistossa vain kerran. Tähän osasyy lienee tosin niiden muodossa: suuri osa frekventatiiviverbeistä kuuluu konsonanttivartaloisiin verbeihin (esim. etsiskellä), joiden olen todennut jo aiemmin esiintyvän harvoin lyhyinä infinitiivimuotoina (ks. alalukua 2.1).

Lisäksi vetosuhteista voidaan havaita, että lyhyt infinitiivi on sekä A-infinitiiviä että illatiivia todennäköisempi perfektissä, pitkäkestoisten prosessien esittämisessä ja vähittäisyyden ilmausten yhteydessä. Tämän aineiston nojalla lyhyt infinitiivi toimii siis monenlaisissa sekä A-infinitiivin että illatiivin tehtävissä, eikä ole syytä olettaa, että ainakaan nämä merkitystekijät estäisivät lyhyen infinitiivin leviämistä. Kuitenkin tapaukset, joissa täydennys on frekventatiivi, tekijä ei ole spesifi tai toiminta on dynaamista, näyttävät suosivan ennemmin A-infinitiiviä tai illatiivia kuin lyhyttä infinitiivimuotoa. Aineiston pieni koko ja suuri hajonta aiheuttavat kuitenkin sen, että kovin suurella varmuudella edellä esitettyjä tendenssejä ei voida todistaa: kun tarkastellaan luottamusvälejä, yksikään selittävä tekijä ei saa kokonaisuudessaan alle yhden tai yli yhden meneviä arvoja. Infinitiivimuotojen merkitysten lähempi tarkastelu jääkin jatkotutkimuksen varaan. 


\subsection{Kohti yhtä infinitiiviä?}

Kieliopillistumispolku tulosijaisesta muodosta yleisinfinitiiviksi on maailman kielissä yleisesti havaittu (Haspelmath 1989), ja osaltaan myös A-infinitiivin lyhyt muoto on noudattanut tätä kaavaa, kun se on siirtynyt alun perin tulosijaisesta latiivista abstraktimpiin tehtäviin (Saukkonen 1965; Sorsakivi 1982). Onkin syytä vertailla A-infinitiivin latiivin historiallista kehitystä lyhyen infinitiivin kehitykseen: molemmissa tapauksissa on edetty kohti yhtä - sijansa ainakin osittain menettänyttä - yleisinfinitiiviä, joka toimii monissa infinitiivisissä tehtävissä. Saukkonen esittää, että latiivin lisäksi itämerensuomalaisissa kielissä olisi ollut muitakin A-infinitiivin tulosijaisia vastineita ikään kuin selventämässä infinitiivin tulosijaisuutta (Saukkonen 1965: 20-21). Itämerensuomen kantakielivaiheessa A-infinitiivin latiivin rinnalle kehittynyt MA-infinitiivin illatiivi on lopullisesti täydentänyt tämän aukon. Ainakin Helsingin puhekielessä tendenssi tuntuu jälleen olevan kohti yhtä infinitiiviä, mutta pohdittavaksi jää, ilmaantuuko sen rinnalle jälleen selvästi tulosijaisempi muoto.

Toinen - infinitiivijärjestelmän ulkopuolinen - selitys lyhyen infinitiivin yleistymiselle on sanahahmojen mallivaikutus. Infinitiivien mallina vaikuttaa selvästi olevan kaksitavuinen ja pitkään vokaaliin päättyvä muoto, kuten antaa. Analogian vaikutuksesta antaa-hahmo on levinnyt myös muihin verbinmuotoihin (esim. kertoo, istuu). Tässä yhteydessä pitää muistaa myös Itkosen (1964) esittämä supistumaverbien analogiapolku. Nämä kolme muotoa voidaan esittää rinnakkain:

$$
\frac{\text { hän antaa }}{\text { pitää antaa }}=\frac{\text { hän kertoo }}{\text { pitää kertoo }}=\frac{\text { hän pelaa }}{\text { pitää pelaa }}
$$

Ajatusta sanahahmon mallivaikutuksesta tukee se havainto, että sanahahmon yleisyys Helsingin puhekielessä ei rajoitu vain infinitiiveihin, vaan vastaavaa hahmoa edustavat esimerkiksi passiivimuodot (mentii, mennää), A-loppuiseen vokaaliyhtymään päättyvät muodot (kelloo, korkee), verbien kolmannen persoonan muodot (hän pelaa, ne pelaa), eräät pronominimuodot (mikää, mitää, kukaa, ketää) ja lisäksi eräät yksittäiset sanat (sillee, tällee < sillä tavalla, tällä tavalla; oikee, melkee < oikein, melkein; nopee < nopeasti). Sanahahmo vaikuttaa osaltaan myös siihen, miksi $d A$-verbit eivät muutu lyhyiksi infinitiiveiksi: ne eivät voi asettua samaan muottiin vartalonsa takia. Tästä syystä vaikuttaakin todennäköisemmältä, että lyhyt infinitiivi leviää ennemmin konsonanttivartaloisiin verbeihin (juosta) kuin $d A$-verbeihin (saada), koska konsonanttivartaloisista verbeistä voidaan tehdä myös kaksitavuinen vokaalivartalo, jonka loppuvokaali pidentyy: pitää juoksee. Suomessa on jo pitkään havaittu konsonanttivartaloiden muutoksia vokaalivartaloiksi, joskin etenemisen on todettu tapahtuvan jopa yksittäinen lekseemi kerrallaan (Paunonen 2003: 201-209; diffuusioilmiöistä suomen kielessä ks. Mielikäinen 1995).

Tässä tutkimuksessa olen osoittanut, että lyhyt infinitiivi on yleistynyt jokaiselta vuosikymmeneltä toiselle siirryttäessä. Osaltaan tärkeä havainto on se, että lyhyt infinitiivi ei ole 1970-luvunkaan aineistossa harvinainen, vaan se kattaa jopa 32 \% kaikista esiintymistä (kuvio 2 s. 38). Näin ollen variaatiotilanne ja muutoksen siemen on jo paljon vanhempi kuin mihin tämän aineiston avulla on mahdollista päästä käsiksi, vaikka lyhyen infinitiivi- 
muodon kasvu kaikkein yleisimmäksi variantiksi onkin tapahtunut vasta 1990-luvun alun jälkeen. Tulevaisuuden tilanteen ennustaminen käykin sikäli vaikeaksi, että selvin muutos on jo tapahtunut. Lyhyen infinitiivin leviäminen konsonanttivartaloisiin verbeihin (tai jopa $d A$-verbeihin) vaatii jo huomattavaa infinitiivien uudelleentulkintaa. Näin ollen voitaisiin ennustaa, että lyhyt infinitiivi kyllä yhä yleistyy niissä muotoryhmissä, joissa sen yleistyminen on mahdollista. Sen sijaan sen koko systeemin läpäisevä produktiivisuus näyttää tämän tutkimuksen valossa vielä epätodennäköiseltä. Yhden infinitiivin systeemiin on olemassa analogian kautta syntynyt mahdollisuus, mutta sen toteutuminen lienee useampien sukupolvien takana. Näin pitkälle menevän muutoksen ennustaminen on käytännössä mahdotonta, koska jo yhteiskunnan muutos tällaisella ajanjaksolla on valtava (Hurtta 1999: 86-87; Laasanen 2016: 67-68).

Toinen lyhyen infinitiivin etenemistä jarruttava tekijä on sen osittainen ikäsidonnaisuus: nuorten ryhmä käyttää lyhyttä infinitiiviä suhteellisesti huomattavan paljon, mutta puhujien ikääntyessä variantin suosio laskee. Jotta tähän asti havaittu muutos on voinut tapahtua, on sen täytynyt kuitenkin olla myös sukupolvittaista (tai elinikäistä), eli vaikka lyhyen infinitiivimuodon käyttö on vähentynyt sukupolven ikäännyttyä, se ei kuitenkaan ole loppunut kokonaan. Näin jokainen sukupolvi on käyttänyt lyhyttä infinitiivimuotoa aina hieman enemmän kuin edellinen sukupolvi, jolloin koko yhteisö on muuttunut ajassa. Vaikuttaa siltä, että ikäsidonnaisuus koskettaa nimenomaan MA-infinitiivin illatiivin tehtävissä toimivia lyhyitä infinitiivejä (ks. kuviota 1 s. 37). Näin voitaisiin todeta, että lyhyen infinitiivin käyttö MA-infinitiivin illatiivin tehtävissä on selvästi nuorille leimallista, kun taas A-infinitiivilähtöisissä tapauksissa tällaista leimautumista ei ole. Jotta lyhyt infinitiivi voisi aidosti vakiintua systeemiin, täytyisi muodon kenties muuttua puhujien silmissä neutraalimmaksi (vrt. Mantila 2004).

Tässä luvussa olen eritellyt lyhyen infinitiivin taustaa ja jäsentymistä osaksi infinitiivijärjestelmää. Leviämismalleiksi olen esittänyt toisaalta järjestelmällisten äänteenmuutosten vakiintumista infinitiiveihin analogian vaikutuksesta ja toisaalta näiden uusien infinitiivimuotojen mallivaikutusta. Olen todennut myös sanahahmojen vaikuttavan infinitiivin yleistymiseen. On luonnollista tulkita lyhyen infinitiivin irtautuvan ajan myötä lähtöinfinitiiveistään ja vakiintuvan omaksi yleisinfinitiivikseen. Sen sijaan sen vakiintumisen vaikutus kahteen muuhun infinitiiviin jää tulevien tutkimusten näytettäväksi. Tässä tutkimuksessa olen osoittanut, että infinitiivijärjestelmässä on selviä muutostendenssejä, mutta muutoksen etenemisen ennustaminen on vaikeaa. Systeemin nykyistä, kolmen infinitiivin tilannetta pitävät yllä muutamat verbinmuodot, jotka eivät toistaiseksi juuri edustu lyhyinä infinitiivimuotoina. Vastaavasti lyhyt infinitiivi vaikuttaa tämän tutkimuksen reaaliaikaisen aineiston valossa olevan osittain ikäsidonnainen piirre, jonka käyttö vähenee puhujien ikääntyessä mutta ei siinä määrin, ettei tapahtuisi myös sukupolvittaista muutosta.

\section{Lopuksi}

Olen tarkastellut tässä artikkelissa kolmen yleisinfinitiivin variaatiota Helsingin puhekielessä 1970-luvulta 2010-luvulle. Analyysini osoittaa, että muutamat tunnetut äänteen- 
muutokset ajavat A-infinitiivin lyhyen muodon (latiivin) ja MA-infinitiivin illatiivin samanmuotoisiksi. Tämän systeemiin syntyneen infinitiivimuodon olen nimennyt lyhyeksi infinitiiviksi ja tulkinnut sen eriävän analogian vaikutuksesta kahdesta muodosta omilleen. Tutkimukseni keskeinen tulos on lyhyen infinitiivin yleistyminen niin, että se on 2010-luvulla jo kaikkein yleisin infinitiivimuoto. Muutos on ollut sukupolvittaista ja alkanut jo ennen tämän aineiston ensimmäistä haastattelukierrosta. Erityisesti MAinfinitiivin illatiivin tehtävissä toimivat lyhyet infinitiivimuodot (meen kertoo) ovat ikäsidonnaisia ja nuorten puheelle leimallisia. Puhujien ikääntyessä illatiivimuodot (kertomaan) lisääntyvät ja nuorille leimalliset piirteet jäävät vähemmälle kuin pelkällä näennäisaikaoletuksella voitaisiin päätellä. A-infinitiivilähtöisissä tapauksissa (pitää kertoo) tällaista leimallisuutta ei ole.

Lyhyt infinitiivi kiinnittyy edelleen lähtöinfinitiiveihinsä, mikä voidaan huomata etenkin sananrajalla tapahtuvista ilmiöistä: A-infinitiivilähtöiset lyhyet infinitiivit toteuttavat rajageminaatiota, kun taas MA-infinitiivilähtöisten tapausten loppu- $n: n$ assimilaatiossa on horjuntaa. Myöskään merkityksen tasolla ei ole havaittavissa suuria eroja infinitiivien välillä. Näin ollen voidaan tulkita, että lyhyen infinitiivin irtaantuminen lähtöinfinitiiveistään ja matka kohti paljasta deverbaaliutta on vielä kesken, vaikka merkkejä siitä on olemassa. Eteneminen kohti yhtä yleisinfinitiiviä saamen tai indoeurooppalaisten kielten tapaan ei siis vielä näytä selvältä, vaan sen toteutuminen jää tulevien tutkimusten tarkasteltavaksi. Muutoksen etenemistä hidastavat erityisesti muutamat verbityypit (konsonanttivartaloiset ja $d A$-verbit), jotka eivät vielä juuri edustu lyhyinä infinitiiveinä, ja toisaalta lyhyen infinitiivin osittainen leimallisuus nuorten puhekieleen kuuluvana piirteenä.

\section{Lähteet}

\section{Aineistolähteet}

Helpuhe $\mathbf{2 0 1 4}$ = Helsingin yliopisto, suomen kielen, suomalais-ugrilaisten ja pohjoismaisten kielten ja kirjallisuuksien laitos, Kotimaisten kielten keskus \& Paunonen, Heikki (2014). Helsingin puhekielen pitkittäiskorpus (1970, 1990, 2010) [puhekorpus]. Kielipankki. http://urn.fi/urn:nbn:fi:lb-2014073041.

\section{Kirjallisuuslähteet}

Anttila, Raimo 1989: Historical and comparative linguistics. Toinen painos. Amsterdam: Benjamins.

Buchstaller, IsABelle 2015: Exploring linguistic malleability across the life span. Age-specific patterns in quotative use. - Language in Society 44 s. 457-496. https://doi.org/10.1017/ soo47404515000391.

Chambers, J. K. - Trudgill, Peter 1998: Dialectology. Toinen painos. Cambridge: Cambridge University Press. https://doi.org/10.1017/cbo9780511805103.

Cox, DAVID 1958: The regression analysis of binary sequences. - Journal of the Royal Statistical 
Society B 20 s. 215-242.

HASPELMATH, MARTin 1989: From purposive to infinitive - a universal path of grammaticization. - Folia Linguistica Historica 10 s. 287-310. https://doi.org/10.1515/flih.1989.10.1-2.287.

Herlin, Ilona 2012: Miksi alkaa tekemään? - Ilona Herlin \& Lari Kotilainen (toim.), Verbit ja konstruktiot s. 143-174. Suomi 201. Helsinki: Suomalaisen Kirjallisuuden Seura.

Herlin, Ilona - Leino, Pentti - Visapä̈̈, Laura 2005: Kas siinä pulma. - Ilona Herlin \& Laura Visapää (toim.), Elävä kielioppi. Suomen infiniittisten rakenteiden dynamiikkaa s. 9-38. Helsinki: Suomalaisen Kirjallisuuden Seura.

Herlin, Ilona - Visapä̈̈, LAUra (toim.) 2005: Elävä kielioppi. Suomen infiniittisten rakenteiden dynamiikkaa. SKST 1021. Helsinki: Suomalaisen Kirjallisuuden Seura.

Hurt ta, Heıк i 1999: Variaationtutkimuksen myytit ja stereotypiat. - Urho Määttä, Pekka Pälli \& Matti K. Suojanen (toim.), Kirjoituksia sosiolingvistiikasta s. 53-101. Tampere: Tampereen yliopiston suomen kielen ja yleisen kielitieteen laitos.

It konen, Terho 1964: Proto-Finnic final consonants. Their history in the Finnic languages with particular reference to the Finnish dialects. Helsinki: Suomalais-Ugrilainen Seura.

— 1989: Nurmijärven murrekirja. SKST 498. Helsinki: Suomalaisen Kirjallisuuden Seura.

Jomppanen, Marjatta 2009: Pohjoissaamen ja suomen perusinfinitiivi vertailussa leat ja olla -verbien yhteydessä. Acta Universitatis Ouluensis B 92. Oulu: Oulu University Press.

Karlsson, Fred - Lehtonen, JA A Kко 1977: Alkukahdennus. Näkökohtia eräistä suomen kielen sandhi-ilmiöistä. Turku: Turun yliopiston suomalaisen ja yleisen kielitieteen laitos.

Kuparinen, Olli 2015: Kohti ääretöntä. Jäsentyvä infinitiivikonstruktiojoukko Helsingin puhekielessä 1970-luvulta 2010-luvulle. Suomen kielen pro gradu -tutkielma. Tampereen yliopisto. http://urn.fi/URN:NBN:fi:uta-201512112521.

Kurкi, Tоммі 2005: Yksilön ja ryhmän kielen reaaliaikainen muuttuminen. SKST 1036. Helsinki: Suomalaisen Kirjallisuuden Seura.

- 2007: Variaationtutkimuksen nykynäkymiä. - Sananjalka 49 s. 143-162.

_ 2013: Näennäisaikametodi ja muutosmallit. - Sananjalka 55 s. 202-212.

LAASANEn, Мıкко 2016: Näennäisaikametodin taustaoletusten teoreettista tarkastelua. - Virittäjä 120 s. 57-83.

Labov, William 1994: Principles of linguistic change vol. 1. Internal factors. Oxford: Blackwell.

LAPPALAInEN, HANnA 2001: Sosiolingvistinen katsaus suomalaisnuorten nykypuhekieleen ja sen tutkimukseen. - Virittäjä 105 s. 74-101.

_ 2004: Variaatio ja sen funktiot. Erään sosiaalisen verkoston jäsenten kielellisen variaation ja vuorovaikutuksen tarkastelua. SKST 964. Helsinki: Suomalaisen Kirjallisuuden Seura.

LeHtonen, Heini 2006: Morfologinen variaatio maahanmuuttajataustaisten helsinkiläisnuorten puheessa. - Kaisu Juusela \& Katariina Nisula (toim.), Helsinki kieliyhteisönä s. 255-274. Helsinki: Helsingin yliopiston suomen kielen ja kotimaisen kirjallisuuden laitos.

LEINO, JA A KКо 2003: Antaa sen muuttua. Suomen kielen permissiivirakenne ja sen kehitys. SKST 9oo. Helsinki: Suomalaisen Kirjallisuuden Seura.

Mantila, Harri 2004: Murre ja identiteetti. - Virittäjä 108 s. 322-346.

Meyerhoff, Miriam 2011: Introducing sociolinguistics. Toinen painos. London: Routledge.

MielikëInen, Aila 1995: Morfologinen diffuusio. - Virittäjä 99 s. 321-334.

Mustanoja, LiIsa 2011: Idiolekti ja sen muuttuminen. Reaaliaikatutkimus Tampereen puhekielestä. Acta Universitatis Tamperensis 1605. Tampere: Tampere University Press.

Nuolijärvi, Pirkko - Sorjonen, Marja-Leena 2005: Miten kuvata muutosta? Puhutun kielen tutkimuksen lähtökohtia murteenseuruuhankkeen pohjalta. Helsinki: Kotimaisten kielten tutkimuskeskus. 
Paunonen, Heik i 1995 [1982]: Suomen kieli Helsingissä. Helsinki: Helsingin yliopiston suomen kielen laitos.

2003: Suomen kielen morfologisista muutosmekanismeista. - Lea Laitinen, Hanna Lappalainen, Päivi Markkola \& Johanna Vaattovaara (toim.), Muotojen mieli. Kirjoituksia morfologiasta ja variaatiosta s. 187-248. Kieli 15. Helsinki: Helsingin yliopiston suomen kielen laitos.

2005: Totta vai toiveajattelua. Näennäisaikainen muutos todellisen muutoksen kuvastajana. - Johanna Vaattovaara, Toni Suutari, Hanna Lappalainen \& Riho Grünthal (toim.), Muuttuva muoto. Kirjoituksia Tapani Lehtisen 6o-vuotispäivän kunniaksi s. 13-53. Kieli 16. Helsinki: Helsingin yliopiston suomen kielen laitos.

— 2006: Vähemmistökielestä varioivaksi valtakieleksi. - Kaisu Juusela \& Katariina Nisula (toim.), Helsinki kieliyhteisönä s. 13-99. Helsinki: Helsingin yliopiston suomen kielen ja kotimaisen kirjallisuuden laitos.

PEARSON, KARL 1900: On the criterion that a given system of deviations from the probable in the case of a correlated system of variables is such that it can be reasonably supposed to have arisen from random sampling. - The London, Edinburgh, and Dublin Philosophical Magazine and Journal of Science 50 s. 157-175.

Priıki, KATRI 2017: Hän, se, tää vai toi? Vuorovaikutussosiolingvistinen tutkimus henkilöviittauksista Kaakkois-Satakunnan nykypuhekielessä. Annales Universitatis Turkuensis C432. Turku: Turun yliopiston julkaisuja.

Rapola, MART Ti 1966: Suomen kielen äännehistorian luennot. SKST 283. Helsinki: Suomalaisen Kirjallisuuden Seura.

Sankoff, Gillian 2005: Cross-sectional and longitudinal studies. - Norbert Dittmar, Klaus J. Mattheier \& Ammon Ulrich (toim.), Sociolinguistics. An international handbook of the science of language and society s. 1003-1013. Berlin: de Gruyter.

SAUKKonen, PAUli 1965: Itämerensuomalaisten kielten tulosijainfinitiivirakenteiden historiaa I. Suomalais-Ugrilaisen Seuran Toimituksia 137. Helsinki: Suomalais-Ugrilainen Seura.

— 1966: Itämerensuomalaisten kielten tulosijainfinitiivirakenteiden historiaa II. SuomalaisUgrilaisen Seuran Toimituksia 140. Helsinki: Suomalais-Ugrilainen Seura.

Siro, PAavo 1964: Infinitiivin asema suomen kieliopissa. - Sananjalka 6 s. 20-26.

SKST = Suomalaisen Kirjallisuuden Seuran Toimituksia.

Sorsakivi, Merja 1982: Infinitiivijärjestelmän muutoksia lasten kielessä. - Virittäjä 86 s. 377-391.

Sturtevant, Edgar H. 1917: Linguistic change. An introduction to the historical study of language. Chicago: Chicago University Press.

VISA Pä̈̈, LAURA 2008: Infinitiivi ja sen infiniittisyys. SKST 1181. Helsinki: Suomalaisen Kirjallisuuden Seura.

VISK = Hakulinen, Auli - Vilkuna, Maria - Korhonen, Riitta - Koivisto, Vesa - Heinonen, Tarja Riitta - Alho, Irja 2004: Iso suomen kielioppi. Helsinki: Suomalaisen Kirjallisuuden Seura. Verkkoversio. http://scripta.kotus.fi/visk URN:ISBN:978-952-5446-35-7 (24.1.2018).

Wagner, Suzanne - Sankoff, Gillian 2011: Age grading in the Montréal French inflected future. - Language Variation and Change 23 s. 275-313. https://doi.org/10.1017/ So954394511000111.

Wierzbicka, Anna 1988: The semantics of grammar. Amsterdam: John Benjamins.

YLIKOSKI, JUSSI 2005: Puhekielen morfologisten ja semanttisten innovaatioiden tutkimusnäkymiä - esimerkkinä suomen tekeen- ja tekees-tyyppiset verbimuodot. - Puhe ja kieli 25 s. 187-209. 


\section{Variation and change in the use of infinitives in Helsinki Finnish}

The article examines the two most frequent infinitives in Finnish - the lative of the Ainfinitive (pelata) and illative of the MA-infinitive (pelaamaan). It also presents a contamination form of the two, termed the 'shortened infinitive' (pelaa). All three forms roughly mean 'to play'. The analysis is based on the longitudinal corpus of the Finnish variety spoken in Helsinki. The corpus contains interviews recorded in the 1970s, 1990 s and 2010s. The aim of the article is to examine variation and change in the use of these three different infinitive forms over a period of time in three different age groups. In addition, the article seeks to examine the underlying causes and patterns of such change.

The article shows that change in the use of infinitives in Helsinki is both generational and an example of age-grading. The use of the shortened infinitive is typical of the youngest age group, whereas older speakers prefer other infinitive forms. Although there is slight idiolectic change (when focusing on the informants interviewed in the earlier rounds of the project), each subsequent generation uses the shortened infinitive more frequently than the preceding generation. This leads to change within the community over time.

The shortened infinitive is the most frequent infinitive form in the 2010s. It is used to represent the functions both of the A-infinitive and the MA-infinitive. Some earlier studies have suggested that there may be a tendency towards using only one infinitive in Finnish, as is the case in many Indo-European languages. This study also indicates that such on-going change may eventually lead Finnish in this direction. However, this is only a case of partial productivity: some verb forms have not yet shortened in Helsinki at all. Thus, it must be left for future studies to evaluate whether the shortened infinitive will ever fully replace the two other infinitives. The article nevertheless presents a thorough overview of the incipient changes in the infinitive system. 


\section{Infinitiivien variaatio ja muutos Helsingissä}

Artikkeli tarkastelee suomen yleisimpiä infinitiivimuotoja, A-infinitiivin latiivia ( $p e-$ lata) ja MA-infinitiivin illatiivia (pelaamaan), sekä näiden yhteenlankeamisesta syntynyttä infinitiivimuotoa, lyhyttä infinitiiviä (pelaa). Aineistona käytetään Helsingin puhekielen pitkittäiskorpusta, joka sisältää haastatteluja 1970-, 1990- ja 2010-luvuilta. Artikkelin tarkoituksena on selvittää kolmen infinitiivimuodon variaatiota ja muutosta kolmella vuosikymmenellä ja kolmessa ikäryhmässä variaationanalyysin keinoin. Tutkimuksen kohteena ovat myös muutoksen etenemisen mallit ja muutoksen taustalla vaikuttavat syyt.

Tulokset osoittavat, että Helsingin puhekielen infinitiiveissä tapahtuu kahdenlaista muutosta: ikäsidonnaista ja sukupolvittaista. Lyhyt infinitiivi on erityisesti nuorten puhekielelle tyypillinen piirre, jonka käyttö on sitä vähäisempää, mitä vanhemmista puhujista on kyse. Toisaalta jo aiemmilla kierroksilla haastatellut puhujat ovat säilyttäneet melko hyvin infinitiivivarianttinsa. Näin koko yhteisö muuttuu, kun muutos etenee sukupolvittain.

Lyhyt infinitiivi on 2010-luvulla jo kaikkein yleisin infinitiivimuoto. Sitä käytetään sekä A-infinitiivin että MA-infinitiivin tehtävissä. Aiemmin on ounasteltu, että suomessa saattaisi olla meneillään tendenssi kohti yhtä yleisinfinitiiviä esimerkiksi indoeurooppalaisten kielten tapaan. Artikkelissa osoitetaan muutos tähän suuntaan, mutta kyse on kuitenkin osittaisesta produktiivisuudesta: $d A$-verbit (esim. saada) ja konsonanttivartaloiset verbit (esim. juosta) eivät vielä juuri esiinny lyhyinä infinitiiveinä. Näin lyhyen infinitiivin mahdollinen muutos yhdeksi yleisinfinitiiviksi kahden muun tilalle jää myöhempien tutkimusten arvioitavaksi, vaikka tässä artikkelissa luodaankin jo kattava katsaus infinitiivijärjestelmässä orastaviin muutoksiin.

Kirjoittajan yhteystiedot (address):

etunimi.sukunimi@uta.fi

Kirjoittaja on väitöskirjatutkija Tampereen yliopistossa. 